\title{
Current Therapeutic Interventions for COVID-19
}

\section{Güncel Bilgiler Işığında COViD-19'da ilaç Tedavisi}

\author{
(1) Hacer Efnan Melek ARSOY11, (D) Öner ÖZDEMIR²
}

1Sakarya University Training and Research Hospital, Clinic of Child Health and Diseases, Sakarya, Turkey

${ }^{2}$ Sakarya University Training and Research Hospital, Division of Pediatric Allergy and Immunology, Sakarya, Turkey

\begin{abstract}
Severe acute respiratory syndrome coronavirus- 2 is an important infectious agent that was first detected in China, causing the pandemic and death of thousands of people. Although the clinic of this disease, called coronavirus disease-19 (COVID-19), is variable, cytokine storm and different mechanisms can cause increased mortality as a result of progressive and serious clinical presentations. Since it belongs to a well-known group of viruses, researchers have gained momentum after the isolation and the identification of the features of the virus. Although specific drugs began to be developed, the first potential candidate drugs were drugs such as broad-spectrum antibiotics, antiviral agents, anti-parasitic agents, and interferon, which were planned to be used with similar indications before pandemic. Trials on all steps such as prophylactic and supporting therapies, as well as care for critically ill patients and vaccine investigation studies are still ongoing. The drugs used in the light of the guidelines were frequently updated and some changes were made as a result of reports on side effects and efficacy evaluations. Especially in some drug combinations, side effects like prolonged QT interval, drug-drug interactions, and restrictions on the use of some drugs in the pediatric age group or pregnancy limit the specific, evidence-based and reliable treatment. Although there are many drugs in the trial phase for COVID-19 treatment, the most promising and most effective drugs are discussed and summarized under the light of national guidelines and clinical evidences with all aspects of the literature.
\end{abstract}

Keywords: SARS-CoV-2, 2019-nCoV, COVID-19, drug treatment

\section{ÖZ}

Şiddetli akut solunum sendromu koronavirüs-2, ilk defa Çin'de tespit edilmiş, pandemiye ve binlerce insanın ölümüne yol açmış önemli bir enfeksiyon ajanıdır. Koronavirüs hastalı̆̆ı-19 (COVID-19) adı verilen hastalığın kliniği değişken olmakla birlikte neden olduğu sitokin firtınası ve farklı mekanizmalar, ilerleyici ve ağır klinik tablolar sonucunda ölümle sonuçlanabilir. Virüsün izolasyonundan sonra özelliklerinin tanımlanması ve iyi bilinen bir virüs ailesine ait olması nedeniyle araşıtırmalar hız kazanmıştır. Hedefe yönelik uygun ilaçlar geliştirilmeye başlansa da ilk potansiyel aday ilaçlar, pandemiden daha önce benzeri endikasyonlar ile üretilmiş olan geniş spektrumlu antibiyotikler, antiviral ajanlar, anti-parazit ajanlar ve interferon gibi ilaçlardır. Profilaksi, destekleyici tedaviler, kritik hasta tedavisi ve aşı üzerine çalışmalar devam etmektedir. Kılavuzlar ışığında önerilen ilaçların kullanımı sonrasından ortaya çıkan yan etkiler ve etkinlik değerlendirmeleri sonucunda tedavi algoritmaları sıkça güncellenmiş ve bazı değişiklikler yapılmıştır. Özellikle bazı ilaç kombinasyonlarında QT süresinin uzama potansiyeli taşıması gibi yan etkilerin olması, ilaç-ilaç etkileşimleri, çocuk yaş grubu ya da gebelik döneminde kullanımıyla ilgili kısıtlamaların olması, özgün, kanıta dayalı ve güvenilir bir tedavinin olmasını kısıtlamaktadır. COVID-19 tedavisi için deneme aşamasında birçok ilaç olmasına rağmen, en umut verici ve en etkili ilaçlar literatürdeki tüm yönleriyle ulusal kılavuzlar ve klinik kanıtlar ışığında tartışılmakta ve özetlenmektedir.

Anahtar Sözcükler: SARS-CoV-2, 2019-nCoV, COVID-19, ilaç tedavisi

Address for Correspondence: Öner ÖZDEMiR, Sakarya University Training and Research Hospital,

Division of Pediatric Allergy and Immunology, Sakarya, Turkey

Received: 05.06.2020

E-mail: ozdemir_oner@hotmail.com ORCID ID: orcid.org/xxxxxxxxxxxxxxxxxx

Cite this article as: Arsoy HEM, Özdemir Ö. Current Therapeutic Interventions for COVID-19. Bezmialem Science 2020;8(Supplement 3):105-16. 


\section{Introduction}

Coronavirus disease-2019 (COVID-19) is a pandemic and worldwide growing public health problem. There is currently no described specific established treatment for this disease. The beneficial and appropriate drug should be specific, effective in its highest level, proven with trials and suitable for pharmacological treatment. As the pandemic spreads rapidly and causes deaths, therapy is urgently becoming essential.

Some medicines which are utilized for other diseases, could potentially be beneficial for severe acute respiratory syndrome coronavirus-2 (SARS-CoV-2) infection without definitive evidences. At this point, the therapeutic approach should be based on infections coming from similar backgrounds with similar effects.

Structural parts of coronavirus (e.g. trimeric spike (S) protein, viral DNA) or some parts from life circle (e.g. proteases, hemagglutinin esterase, NTPase/helicase, and endosomal $\mathrm{pH}$ challenges ) are important target points for developing drugs (1) (Figure 1).
The objective of this study is to examine drugs with a higher level of evidence, which are recommended or started to be used in COVID-19 treatment. Some of these medicines are known in literature with similar indications from the past. Under the light of current guidelines, these drugs are examined according to their recommendation level and effectiveness in use.

\section{General Palliative/Supportive Treatment}

Since there is no specifically defined treatment for SARS-CoV-2, the designated therapy should be appropriate for the clinical levels specific to the condition of the patients. Symptomatic treatment includes controlling high fever or pain with an antipyretic patch or antipyretic-analgesic drug treatment. The treatment regimen could be revised to comprehend a broad perspective. Supportive therapy is vital in these patients. General supportive treatment strategies for patients with mild symptoms are shown in Table $1(2,3)$.

\section{Medical Treatment with Drugs}

There is a large number of drugs, which are still in the clinical trial phase to be used in the treatment of COVID-19 disease.

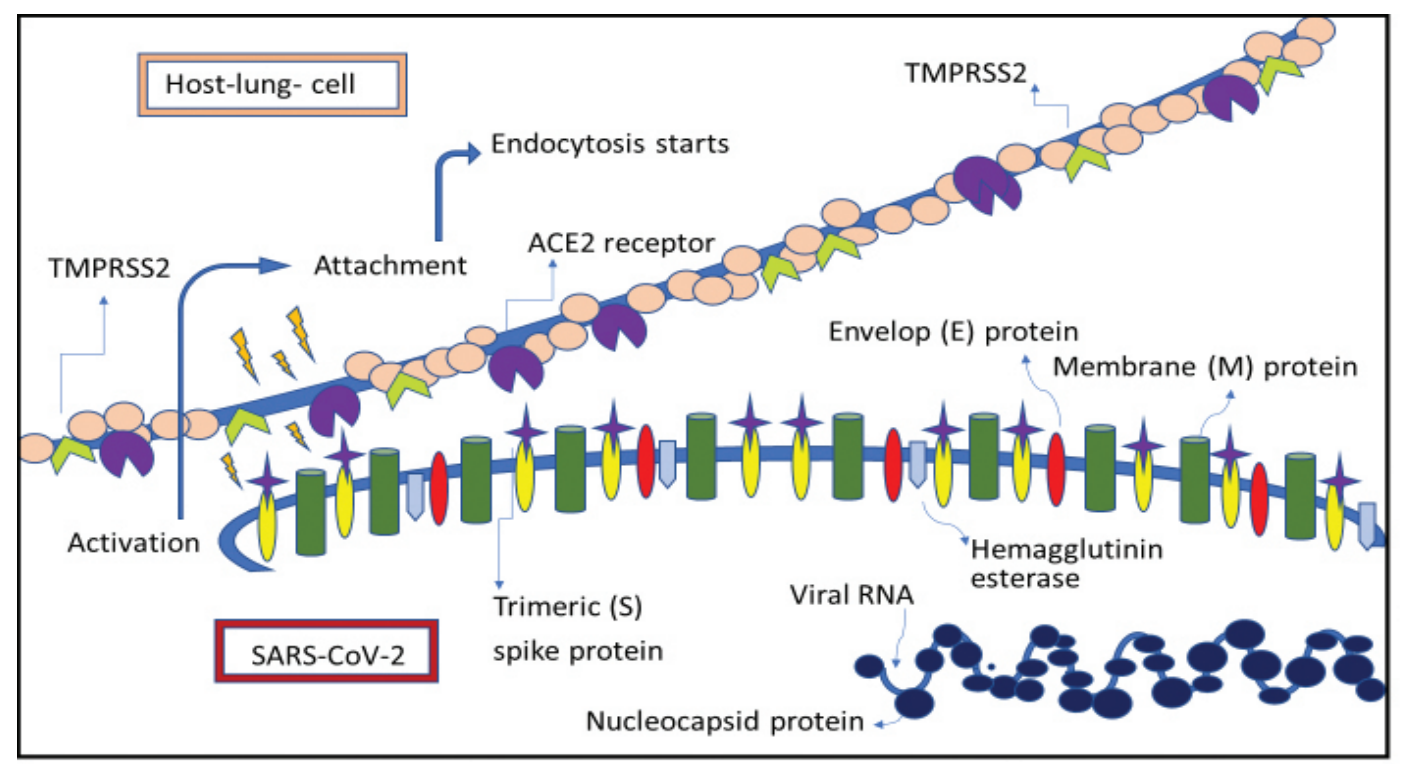

Figure 1. The structural parts of SARS-CoV-2

ACE-2: Angiotensin converting enzyme-2, TMPRSS2: Transmembrane serine protease 2, SARS-CoV-2: Severe acute respiratory syndrome coronavirus-2

Table 1. Supportive treatment options other than specific medications (3)

\section{General treatment strategies}

Bed resting

Ensuring sufficient calory

Adequate water intake

Paracetamol

ibuprofen

C vitamin

$\mathrm{N}$-aceytil cysteine

ECMO: Extracorporeal membrane oxygenation
Supportive care steps in critical illness

Prevent and treat complications, underlying diseases

Secondary bacterial or fungal infection treatment

Complete fluid resuscitation

Lung protective ventilation strategy, $\mathrm{O}_{2}$ support

Prone position ventilation, lung recruitment

Vasoactive drugs

ECMO 
Table 2. Classification of various drugs tried in COVID-19 $(4,5)$

\begin{tabular}{|c|c|c|}
\hline Protease inhibitor & Interferon & Monoclonal antibody \\
\hline -Lopinavir/ritonavir (/+ ribavirin) & & Tocilizumah \\
\hline -Nelfinavir & -Interferon beta $1 \mathrm{~A}$ & -Sarilumah (anti-11 6R) \\
\hline -Camostat mesilate $\mathrm{NI}-03$ & -Interferon beta 1B & CAP-301 \\
\hline -ASCO9 (/+ oseltamivir) & -PEG Interferon Lambda & 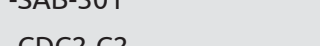 \\
\hline -ASCO9 (/+ ritonavir) & -Interferon Alpha 2A & $15 X-1$ \\
\hline -Darunavir/cobicistat & -Interferon Alpha 2B & $-115-1$ \\
\hline $\begin{array}{l}\text {-Flavopiridol } \\
\text {-Relacatib }\end{array}$ & -Interferon Alpha N3 & -REGN3051 /+REGN3048 \\
\hline Anti-protozoal & RNA polymerase inhibitor & Immunemodulator \\
\hline -Hydroxychloroquine & Epviniravir & -Colchicine \\
\hline -Chloroquine & -ravipiravir & -Hiltonol (poly-IC) \\
\hline -Emetin & -ravipıravıг + interreron-a & -Rintatolimod \\
\hline Nucleoside analogue & Nucleoside analogue + reverse transcriptase inhibitor & Endonuclease inhibitor \\
\hline $\begin{array}{l}\text {-Remdesivir } \\
\text {-Galidesivir }\end{array}$ & -Emtricitabine + tenofovir & -Baloxavir morboxil \\
\hline Immunosuppressant & Fusion inhibitor & NMDA inhibitor \\
\hline -Mycophenolate mofetil & -Arbidol (Umifenovir) & -Ifenprodil \\
\hline Kinase inhibitor & Steroid & Neuraminidase inhibitör \\
\hline -Baricitinib & -Hydrocortisone acetate & -Oseltamivir \\
\hline Ribonucleoside analogue & & \\
\hline -Ribavirin & & \\
\hline
\end{tabular}

Table 3. Various combination therapies in COVID-19 disease $(4,5)$

\begin{tabular}{ll|l|l} 
1. Drug & & 2. Drug & 3. Drug \\
\hline Corticosteroid & + & Rapamycine & Azithromycin \\
\hline Hydroxychloroquine & + & Oseltamivir \\
Favipiravir & + & Tocilizumab \\
Favipiravir & + & Ritonavir \\
Indinavir & + & Mycophenolate mofetil \\
\hline Interferon beta & + & Ritonavir \\
\hline Lopinavir/ritonavir & + & interferon beta \\
\hline Lopinavir/ritonavir & + & interferon beta \\
\hline Ribavirin & + & Mesenchymal stem therapy \\
\hline Ruxolitinib & + & Ribavirin \\
\hline
\end{tabular}

Classification of drugs according to their effect mechanisms and possible combination therapies being utilized are given in Tables 2 and $3(4,5)$.

\section{Chloroquine}

Chloroquine (CQ), a compound from class 4-aminoquinoline, has been used to treat malaria effectively as a cheap treatment based on its clinical safety.

CQ is also used for amebiasis, lupus erythematosus, Sjogren's syndrome and rheumatoid arthritis. Against rheumatoid arthritis, it acts by inhibiting lymphocyte proliferation, phospholipase A2, antigen presentation in dendritic cells, the release of enzymes from lysosomes, reactive oxygen species from macrophages, and production of interleukin (IL)-1 (6).

Lately, it was administered in $\mathrm{CoV}$ infections, SARS-CoV and Middle East respiratory syndrome-CoV (MERS-CoV). It has an effect on the immune system as an immunomodulating agent, inhibits cytokine production by suppressing T-cell activation, autophagy and lysosomal activity in antigen-presenting cells by preventing antigen processing and major histocompatibility complex class II-mediated autoantigen presentation to T-cells, and diminishes viral replication. There are ongoing and finished clinical trials on the use of CQ in COVID-19 disease because the efficacy and safety of CQ is still unsatisfactory (7). 
Impaired terminal glycosylation of angiotensin-converting enzyme-2 (ACE-2) (the cellular receptor of SARS-CoV) may diminish the binding efficiency between ACE-2 on host cells and the SARS-CoV spike protein. Consequently, the binding of the virus to the receptors on the cells is interrupted and infection is averted. CQ also acts as a zinc ionophore, that permits of extracellular zinc insertion through the cell and inhibits viral RNA-dependent RNA polymerase (7).

\section{Chloroquine vs Hydroxychloroquine?}

CQ is used as phosphate and sulfate salt and it is stored in high concentrations in the liver, kidney, spleen, lungs and leukocytes. The half-life varies between 70 and 120 hours depending on the dose. It is slowly excreted from the body (8). The EC50 of CQ for SARS is 4.4 to $8.8 \mu \mathrm{M}$ in in vitro, indicating that CQ could be more potent against COVID-19 than SARS (9).

In a study including 100 patients, CQ inhibited the exacerbation of pneumonia, promoted the conversion of the polymerase chain reaction test to a negative and shortened disease period however more detailed data were not reported (10).

Hydroxychloroquine, is an analogue of $\mathrm{CQ}$, diverges from CQ with a single hydroxyl group attached to the end of the chain, by the way it provides low ocular toxicity. Nowadays, it is used more frequently due to the much lower side effects. Hydroxychloroquine has been shown more potent in vitro activity against SARS-CoV-2 than CQ. EC50 of Hydroxychloroquine is $0.72 \mu \mathrm{M}$ for SARS-CoV-2 $(8,11)$.

Although there are many data streams from all over the world, some of them indicate efficacy and acceptable safety for CQ in COVID pneumonia $(5,10)$. In addition to that 23 trials are continuing, all in China. The trials are differed in study design, the severity of COVID-19 in the target group and application route and duration of the treatment (8).

A Chinese single center clinical trial (ChiCTR2000030417) which is not recruiting yet $(\mathrm{n}=30,15 / 15)$; is comparing CQ phosphate as an aerosolized inhalation solution to water for atomized inhalation group (12).

In a clinical trial of 36 patients; a significant reduction of the viral carriage has been evidenced at day $6^{\text {th }}$ after inclusion compared to controls with much lower average transfer duration compared to that of reported untreated patients in literature. This trial also shows decreased SARS-CoV-2 shedding with hydroxychloroquine treatment. The combination of hydroxychloroquine and azithromycin has a synergistic effect with a more efficient virus elimination, which, also provides viral carriage reduction. The clinical outcome is good (13).

In a limited study, 368 African American veteran males of different severity stages of COVID-19 disease were retrospectively evaluated. In all 3 groups; application of hydroxychloroquine and azithromycin, alone each or in combination, did not cause a significant decrease in the need for respiratory support and the number of deaths after ventilation. The increased risk of mortality was observed in the hydroxychloroquine group compared to the groups without hydroxychloroquine administration (14).
A study analysis with a multinational registry that was later retracted in June due to insufficient data advocated the restriction of hydroxychloroquine and CQ administration because of increased cardiovascular mortality detected in COVID-19 patients (15).

\section{Dosing of Chloroquine}

Dose arrangement is necessary between CQ phosphate and CQ base since $250 \mathrm{mg}$ of the first one corresponds to $150 \mathrm{mg}$ of the second. Based on pharmacokinetic modeling, a study recommends a dose for hydroxychloroquine $400 \mathrm{mg}$ twice daily for the first day, then $200 \mathrm{mg}$ twice daily for 4 days in the treatment of COVID-19, as it reached three times the potency of CQ phosphate when given $500 \mathrm{mg}$ twice daily for 5 days (8).

Italian Society of Infectious and Tropical Disease, advises using CQ $500 \mathrm{mg}$ twice a day or hydroxychloroquine $200 \mathrm{mg}$ /day for 10 days and suggests adjusting treatment duration from 5 to 20 days, in line with the clinical severity (4).

For pediatric patients, it was also recommended in COVID-19 guideline of the Turkish Ministry of Health in different dosing regimens, $6.5 \mathrm{mg} / \mathrm{kg} /$ dose twice for the first day [maximum (max) $400 \mathrm{mg}$ ] and $3.25 \mathrm{mg} / \mathrm{kg} /$ dose twice for 2-5 days (16).

Side effects of CQ and some clinical conditions to be considered are shown in Tables 4 and 5, respectively $(16,17)$.

\section{Chloroquine in Pregnancy and Lactation}

CQ has not been found to increase the risk of adverse fetal events or any harmful effects on the fetus when used in recommended doses for malarial prophylaxis, according to the American Centers for Disease Control and Prevention (CDC) guidelines. $\mathrm{CQ}$ and its metabolites pass the breast milk and placenta. It can be noticed in the cord blood and urine of the newborn infants (18).

There is not certain assigned pregnancy category by the Food and Drug Administration (FDA).

For children infected by SARS-CoV-2, there is no recommended dosage of CQ thus far. A dose of $50 \mathrm{mg} / \mathrm{kg}$ CQ refers to an acute poisoning and it can be fatal. In a report CQ serum concentration $>25 \mu \mathrm{mol} / \mathrm{L}$ was considered as a predictor of lethality (18).

\section{Mefloquine}

As positive results have been published regarding the use of antimalarial drugs in the treatment of COVID-19, recommendations began to emerge about another anti-malarial drug, mefloquine.

Mefloquine was found to have anti-viral activity against both MERS-CoV and SARS-CoV. The EC50 value of mefloquine is 7,416 for SARS-CoV and hydroxychloroquine sulfate is 7,966, CQ diphosphate is 6,538 (19).

Pangolin coronavirus GX-P2V is a workable model for SARS$\mathrm{CoV}-2$ research and the study has shown that mefloquine hydrochloride is a potential drug for treating SARS-CoV-2 infection (20). 
Table 4. Side effects of chloroquine (17)

Unwanted/uncontrolled movements (including tongue and face twitching)

Deafness or tinnitus

Nausea, vomiting, diarrhea, abdominal cramps

Headache

Shortness of breath

Swelling legs/ankles, muscle weakness

Mental/mood changes (such as confusion, personality changes, unusual thoughts/behavior, depression, feeling being watched, hallucinating)

Signs of serious infection (such as high fever, severe chills, persistent sore throat)

Skin itchiness, skin color changes, hair loss, and skin rashes

Unpleasant metallic taste

Electrocardiographic changes*

Chloroquine retinopathy**

Pancytopenia, aplastic anemia, reversible agranulocytosis, low blood platelets, neutropenia, severe hypoglycaemia

*Electrocardiographic changes include conduction disturbances (bundle-branch block, atrioventricular block) or cardiomyopathy. Hypertrophy, restrictive physiology and congestive heart failure often accompany the conditions which may be irreversible. Only two cases have been reported requiring heart transplantation, suggesting this particular risk is very low. Electron microscopies of cardiac biopsies show pathognomonic cytoplasmic inclusion bodies (67).

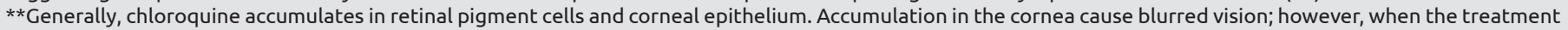

is stopped, this effect will disappear but retinopathy tends to progress and can lead to permanent vision loss.

Table 5. Note some clinical situations before or simultaneously or afterwards proposing use of chloroquine (17)

Rule out the development of anemia, thrombocytopenia or leukopenia

Serum electrolyte disturbances

Hepatic and renal function dysfunction

Routine electrocardiography were recommended (rule out the development of QT interval prolongation or bradycardia)

Patient interviews to seek the appearance of visual and/or mental disturbance/deterioration

Avoid concurrent administration of other drugs known to prolong the QT interval (i.e. kinolones, macrolides, ondansetron) as well as various antiarrhythmic, antidepressant and antipsychotic drugs

Drug-drug interactions

Ask about G6PD deficiency; hepatic impairment, porphyria, seizure disorder*

*Use with caution in these patients; may exacerbate disease symptoms

Also, clinical trials are ongoing, about prophylaxis, efficacy, and safety of mefloquine. CDC suggests the anti-malarial drug mefloquine for pregnant women based on the recent FDA recategorization of mefloquine from a pregnancy category $\mathrm{C}$ drug to category B.

\section{Remdesivir}

Remdesivir (GS-5734) is a mono phosphoramidate prodrug of an adenosine analog and it is manufactured by Gilead Sciences. It inhibits viral RNA polymerases activity of RNA virus families. It inhibits SARS-CoV and MERS-CoV replication in multiple in vitro systems, including primary human airway epithelial cell cultures at submicromolar $\mathrm{IC}_{50}$ values. This drug has also shown activity in a rhesus macque model of MERS-CoV infection. Remdesivir has been currently in clinical trials for the treatment of Ebola virus disease (11).

There has not been yet clearly stated any evidence of safety, optimal dosing, or effectivity for the treatment of COVID-19 disease, only in vitro activity against SARS-COV-2 has been shown (11). Under the light of the latest literature data, FDA has approved the use of this drug in COVID-19 on $1^{\text {st }}$ of May, 2020 (emergency use authorization). The extensive guide published by the FDA provides detailed information about administration and side effects due to elevated transamine levels in the blood and infusion site reactions (21).

Immediately after remdesivir was approved by Japan on May 7, some trials like National Institute of Allergy and Infectious Diseases (NIAID) trial have resulted in some data as the drug helped patients heal faster than standard care, indicating it could become the first efficient therapy for the illness (22).

In a mouse model of SARS-CoV pathogenesis, the prophylactic and early therapeutic use of remdesivir markedly decreased lung viral load and improved clinical condition besides respiratory functions (11).

Airway resistance or accumulation of debris in the airway was markedly $(\mathrm{p}<0.05)$ elevated in vehicle-treated animals (mice) as compared to those treated with GS-5734. Prophylactic 
administration of GS-5734 mitigated lung virus titers, improved lung function, and ameliorated symptoms of COVID-19. On the other hand, therapeutic post-exposure administration of GS5734 appeased illness in this wide spectrum trial (23).

In an unpublished trial, which consists of 12 infected rhesus macaques with SARS-CoV-2, the treated group with remdesivir was significantly healthier than the untreated group and had a less viral load and less damage in lungs (24).

Fifty-three patients' data from multicenters were involved in a trial of compassionate use of remdesivir without any control groups. There were 2 deaths because of adverse effects resulting in liver and renal failure. Thirty-two patients (60\%) were developed adverse events during the treatment period. The most common adverse events were increased hepatic enzymes, diarrhea, rash, renal impairment, and hypotension. Generally, adverse events were more severe in critical cases such as -multiorgan-dysfunction syndrome, septic shock, and hypotension (25).

There is an evidence of in vivo administration of remdesivir for prophylactic and therapeutic use against MERS-CoV infections in mice. Remdesivir improves pulmonary function and severe lung pathology, as well as reduces viral titers in the lung (26). Further, experiments in mice using remdesivir showed higher efficacy than lopinavir/ritonavir + interferon (IFN)- $\beta$ (27).

Moderate or severe ill COVID-19 cases with respiratory problems who received remdesivir, recovered quickly than similar patients who received placebo, according to a preliminary data analysis from a randomized, controlled trial including 1063 hospitalized patients (28).

In contrast, in a double-blind randomized trial including 237 Chinese patients with severe COVID-19 (hypoxia and radiographically confirmed pneumonia), duration to clinical healing was not statistically different with remdesivir compared to placebo for 10 days (29).

NIAID investigates therapeutics, as there is not a clear dose regimen schema for adults and adolescents with acute Ebola virus disease, it suggests as following; single remdesivir $200 \mathrm{mg}$ IV loading dose on the first day of treatment followed by $9^{\text {th }}$ to $13^{\text {th }}$ day (if virus has still been detectable in plasma) once daily $100 \mathrm{mg}$ IV maintenance dose. It has an intracellular half-life of longer than 35 hours.

For pediatric patients with body weight $<40 \mathrm{~kg}$, a body weightbased dosing regimen of one loading dose of remdesivir $5 \mathrm{mg} / \mathrm{kg}$ IV (max $200 \mathrm{mg}$ ) on day 1 , followed by $2.5 \mathrm{mg} / \mathrm{kg} /$ dose IV once daily (max $100 \mathrm{mg}$ ) was used in 41 pediatric patients involving 2 neonates who were in a phase 3 Ebola trial (30).

\section{Ribavirin}

Ribavirin, a guanine analogue, which inhibits viral RNAdependent RNA polymerase in other coronaviruses, is also a candidate for COVID-19 treatment. Nowadays, only in vitro data is available regarding the activity of ribavirin on SARSCoV-2. Ribavirin seems to be less potent in vitro than CQ and remdesivir (11). In a systematic review of ribavirin treatment in patients infected with SARS-CoV, 26 trials were inconclusive, and 4 showed potential harm as in Canada 2003. Additionally, it decreased the amount of hemoglobin as a side effect in cases needing respiratory support $(27,31)$.

An open-label study resulted in 2004, compared a historical control group of 111 cases who were administered only ribavirin with 41 cases who were received a combination of lopinavir/ ritonavir $(400 \mathrm{mg} / 100 \mathrm{mg}$ ) and ribavirin. Ribavirin alone had no significant beneficial effect in reducing adverse clinical outcomes such as death and reducing the viral load of SARS-CoV (32).

\section{Interferons}

Interferons have antiviral properties and they have been evaluated as a potential treatment for COVID-19 disease but with lack of data in this regard. Some clinical trials have not been yet published or concluded, support of using interferons, alone or in a combination.

A clinical trial of 350 critically ill patients with MERS-CoV was evaluated. Mortality rates were higher in patients who received ribavirin and interferon than compared to the group without any medication (33). In 301 patients with ARDS, intravenous IFN- $\beta 1-\alpha$ administration had almost same ventilation time and mortality rate compared to placebo (34). IFN- $\beta$ is better tolerated in terms of its side effects than IFN- $\alpha$.

\section{Lopinavir/Ritonavir}

Lopinavir, a repurposed drug for the treatment of MERS-CoV and SARS-CoV, is an antiretroviral medicine primarily used for human immunodeficiency virus (HIV) infection $(27,32$ ). Lopinavir is combined with ritonavir, which inhibits the cytochrome $\mathrm{p} 450$, by the way plasma half lifetime of lopinavir is extended.

As it has been used for the treatment of HIV-positive pregnants, there is a wide experience for good safety. Although lopinavir is found in the breast milk at a much lower amount, according to World Health Organization (WHO) guidelines, several safer treatment options are recommended to treat HIV-infected mothers (35). It was also recommended by Turkish Ministry of Health, COVID-19 guidelines for use in pediatric patients (16).

According to a clinical trial of the combination of lopinavir/ ritonavir with ribavirin or IFN- $\alpha$, viral load was reduced, and survival improved among SARS and MERS patients $(32,36)$.

Retrospective comparative analysis in MERS, lopinavir/ritonavir ensured ARDS or death reduction from $28 \%$ to $2.4 \%$ (27).

A randomized clinical trial was compared lopinavir-ritonavir therapy and standard-care therapy in hospitalized SARSCoV-2 infected patients. There was no clinical improvement or difference in mortality at 28 days or detectable viral RNA load at various time points. Nevertheless, gastrointestinal adverse events were more common. Although skin eruptions, QT prolongation, pancreatitis, drug interactions due to CYP3A inhibition was observed in the lopinavir-ritonavir group, serious adverse 
events/complications such as ARDS or acute kidney injury and pneumothorax was more common in the standard-care group (37).

\section{Favipiravir}

Favipiravir (T705) is a purine nucleic acid analog of pyrazine carboxamide derivative (6-fluoro - 3-hydroxy - 2pyrazinecarboxamide), which is an antiviral drug developed for the treatment of influenza and it was used during the Ebola virus outbreak. It increased the survival rate and reduced viral load in Ebola virus-infected patients. Nowadays, it is being evaluated for the safety and efficacy in patients with COVID-19 (38). So far registered clinical trials are expected to be beneficial. Clinical trials are ongoing about different dosing regimens of favipiravir alone or combined with tocilizumab, CQ, IFN- $\alpha$ and, other antiviral treatments for the use of COVID-19 disease. In a clinical trial, no evidence of difference in the improvement of patients' condition between favipiravir and arbidol treatment has been shown (39).

For dosing there is a preliminary in vitro and preclinical data from China that the regiment of 3,200 mg/day loading dose on day 1 , followed by 1,200 mg maintenance dose on day 2 to day 14 is effective or, a loading dose is recommended ( 2400 $\mathrm{mg}$ to $3000 \mathrm{mg}$ every 12 hours, 2 doses/day) and followed by a maintenance dose (1200 mg to $1800 \mathrm{mg}$ every 12 hours). The half-life of favipiravir is approximately 5 hours (40).

\section{Corticosteroids}

ARDS is the major lethal clinical picture due to SARS-CoV-2 infection. Corticosteroids can reduce the host inflammatory responses in the lungs with potent anti-inflammatory effects and a potential therapeutic role in suppressing cytokine-associated lung damage with acute lung injury.

During community-acquired pneumonia, the effect of corticosteroid treatment was investigated through the systematic review and meta-analysis of randomized trials. Reduced parameters were found to be mortality $(3 \%)$ and mechanical ventilation support (5\%), and length of hospital stay (about 1 day) (41).

Generally, there is no certain data came up to expect that COVID-19 disease will benefit from corticosteroids. On the other hand, their harmfulness must not be ignored. Some authors conclude that corticosteroid treatment should not be administered for COVID-19-related lung injury treatment or shock without conducting clinical trials. WHO guideline also recommends not to use systemic corticosteroids for the treatment of any viral pneumonia except during clinical trials (42).

The Chinese Thoracic Society has published an expert consensus declaration involved fundamental principles when utilizing corticosteroids in SARS-CoV-2 pneumonia: the benefits and harms should be weighed prior to administering corticosteroids, corticosteroids should be used carefully in advanced stages of illness with SARS-CoV-2 pneumonia, for patients with hypoxemia due to COVID-19 or who regularly use corticosteroids for chronic diseases for further use of corticosteroids should be cautious, and the dose regimen should be low-to-moderate $(\leq 0.5-1 \mathrm{mg} / \mathrm{kg} /$ day methylprednisolone or equivalent) and the therapy period should be less than almost 7 days (43).

Infectious Diseases Society of America Guidelines recommends corticosteroid administration in the patients who hospitalized with ARDS due to COVID-19, not all the hospitalized COVID pneumonia (44).

In contrast, different meta-analysis results of 528 patients showed that prolonged corticosteroid therapy is more effective in severe community-acquired pneumonia to reduce the mortality and risk of ARDS (45). In a systematic review consisting steroid use in 29 COVID-19 patients, 25 were inconclusive and 4 were categorized as causing possible harm (31).

In addition, increased mortality was observed due to the early administration of corticosteroids in 241 patients with Influenzaassociated ARDS (46).

Corticosteroid administration should be evaluated on a caseby-case basis, based on the patient's disease status and severity, indication and underlying medical condition. More clinical research and data are needed.

\section{Vitamin C}

Beyond antiviral and antioxidant properties, vitamin $\mathrm{C}$ has effects on immune system response. It avoids epithelial waterchannel damage due to the limitation of active neutrophil migration to alveolar medium and support for the development of more channels. It is caused by the enhancement of alveolar fluid clearance. Also, it abates lipopolysaccharide-induced acute lung injury.

Short-term high-dose vitamin $\mathrm{C}$ in selected patients may improve hemodynamic parameters, decrease fluid resuscitation requirements, reduce the incidence of perioperative atrial fibrillation, improve pain, and potentially reduce sepsisassociated mortality. High-dose intravenous vitamin $\mathrm{C}$ has also been successfully applied to 50 moderate to severe COVID-19 cases. The oxygenation index was healed in real time and all the cases finally cured (47).

On the other hand, the concern that may occur with high-dose vitamin $\mathrm{C}$ therapy is osmotic cell death of immune cells, but not apoptosis, which could generate a local inflammation in alveolar space. Accordingly, intravenous glucocorticoid treatment must be performed to limit possible inflammatory damage of highdose vitamin C therapy (48).

Also, analysis of the CITRIS-ALI study has shown the efficacy of high dose vitamin C $(50 \mathrm{mg} / \mathrm{kg} / 6 \mathrm{hrs}$.) in preventing mortality from acute lung injuries as compared to placebo. This should be considered for evaluation in COVID-19 treatment (49).

\section{Teicoplanin}

Teicoplanin is a glycopeptide antibiotic used in the treatment of gram-positive bacterial infections, especially staphylococcal infections. Teicoplanin acts on an early stage of the coronaviruses 
and also SARS-COV-2 life cycle by inhibiting the low-pH cleavage of the viral spike protein by cathepsin- $\mathrm{L}$ in the late endosomes, thus avoiding the dissemination of genomic viral RNA and proceeding the virus replication cycle. Recently an experiment showed that this activity was conserved against SARS-CoV-2 (the target sequence that serves as the cleavage site for cathepsin $\mathrm{L}$ is conserved among SARS-CoV spike proteins) (50). Once these preliminary results have been confirmed in a randomized clinical trial, teicoplanin will be useful for the treatment of COVID-19 (51).

\section{Tocilizumab}

Tocilizumab, an IL-6 receptor-inhibiting monoclonal antibody, was first approved by FDA for the treatment of rheumatoid arthritis, juvenile idiopathic arthritis, giant cell arteritis, and chimeric antigen receptor T-cell-induced severe or lifethreatening cytokine release syndrome. The beneficial effect is against the amplified pathological hyperactivity of the immune response observed in COVID-19.

According to a study of 21 patients with severe or critical COVID-19, partial improvement in clinical condition and CT scan image was shown after administration of $400 \mathrm{mg}$ tocilizumab mostly once, in addition to their routine care (52). There are 14 ongoing clinical trials about using tocilizumab for COVID-19 in different dose regimens, alone or in combination, administered intravenously within no less than 60 minutes (53).

The Chinese National Health Commission guidelines suggested using tocilizumab in the management steps of severe COVID-19 with widespread bilateral lung disease and elevated IL-6 (5). The SIMIT Lombardy section guidelines recommended tocilizumab in critically ill patients with ARDS. Side effects can be allergic reactions, fever, chills, increased risk of serious infections, or bleeding, gastritis, liver damage and hepatic failure, leukopenia, neutropenia, thrombocytopenia, muscle weakness, dyspnea, hypertension, etc (4).

Monoclonal antibodies are actively transported across the placenta during the last trimester (pregnancy category C). It is a large protein molecule, the amount in breast milk is likely to be very low and absorption is unlikely because it is probably destroyed in the infant's gastrointestinal tract (52).

\section{Emetine}

Emetine is a protein synthesis inhibitor that was used as antiprotozoan approved for the treatment of ameobiasis, it also inhibits malaria by binding to the ribosomal E site of Plasmodium falciparum. However, it has been used less frequently over the years because it has a significant cardiotoxic effect.

Emetine has antiviral efficacy against a wide range of RNA and DNA viruses and inhibits human $\mathrm{CoV}$ in vitro with $\mathrm{EC}_{50}$ reported at low micromolar. Also, emetine was observed at nearly $0.5 \mu \mathrm{M}$ efficiently interrupting SARS-CoV-2 virus replication in Vero E6 cells (54).

\section{Ivermectin}

It is confirmed by the FDA as a broad-spectrum anti-parasitic effect for the treatment of cutaneous larva migrants. In recent studies, ivermectin has been shown to have an in vitro effect on SARS-CoV-2 caused by reduction in viral RNA without causing any toxicity raised from the nuclear importin- $\alpha / \beta$-mediated transport inhibitory activity. Clinical trials are underway that explore the efficacy of ivermectin alone by real-life experience or combination with hydroxychloroquin and azithromycine, nitazoxanide. Due to their consequential and synergistic manner, ivermectin is recommended as a proposition to use in combination with hydroxychloroquine with no serious drugrelated adverse events (55).

In a clinical study 1400 hospitalized SARS-CoV-2 infected patients were treated with $150 \mathrm{mcg} / \mathrm{kg}$ of ivermectin once while the second group (control group) adhered to the treatment protocol (not included ivermectin). It was found that there was a decrease in hospitalization period and mortality in the ivermectin group (56).

\section{Oseltamivir}

Oseltamivir is a neuraminidase inhibitor that has a proven beneficial effect on prophylaxis and treatment of influenza. It has taken its place among the treatment alternatives of COVID-19 due to its low side effects such as nausea and vomiting. There isn't any identified enzyme or mechanism indicating the effectivity of oseltamivir on coronavirus. Thus, its mechanism of action is not clear. Even so, it has participated in combinations of antiviral therapy in China (57). Trials evaluating only combination regimens are underway.

Intravenous Immunoglobulin and other Immunomodulator Agents

Intravenous immunoglobulin (IVIG) has many indications as a part of combination therapies in treatment of several diseases including adjuvant therapy in a more pathogen-focused (hyperimmune) form.

Convalescent (immune) plasma is a kind of plasma obtained from the patients recently recovered SARS-CoV-2 infection. It has been accepted as passive antibody therapy in the other $\mathrm{CoV}$ infections as well. The issues are regarding its application quantity to appropriate patients. It is recommended to be used in the lastline treatment group, especially in critically ill patients (58). Nevertheless, there are few case reports regarding administration of IVIG for COVID-19 treatment (58). The results of 7 trials of convalescent plasma or IVIG on the SARS-infected patient were inconclusive (31).

During the SARS outbreak, approximately $30 \%$ of critically ill patients developed venous thromboembolism despite the prophylactic use of low-molecular weight heparin. It was supposed to be developed due to the IVIG-induced increase of viscosity in hypercoagulable states of SARS patients (59).

Although there are different views about the use of IVIG, a study was conducted in 58 SARS-CoV-2 infected patients. IVIG 
administration within 48 hours of admission of the patients to the intensive care unit, has been shown to be effective in reducing the use of mechanical ventilation, hospital length of stay and mortality of patients with severe COVID-19 pneumonia (60).

Immunomodulatory agents can be necessary before multi-organ dysfunction to attenuate systemic inflammation. Corticosteroids may use in compatibly with cytokine inhibitors such as tocilizumab or anakinra (IL-1 receptor antagonist). Generally, recovery from this advanced severe stage of illness is rare, and immediate recognition of condition and administration of such therapy may be the most vital point (61).

Hemophagocytic lymphohistiocytosis (HLH), is a severe and rare condition which can be develop in no more than 0.25 $1 \%$ of COVID-19 patients during cytokine storm syndrome. Corticosteroids, IVIG, tocilizumab, anakinra, JAK inhibitors and even chemotherapeutics can be used for treatment of HLH. IVIG treatment can be administered for 2 days at the dose of 2 $\mathrm{g} / \mathrm{kg} /$ day with immunoglobulin level monitoring (should not be used in IgA deficiency) (16).

COVID-19 Treatment Guidelines Panel suggests not to use the following drugs for the treatment of COVID-19: The combination of hydroxychloroquine plus azithromycin because of the potential for toxicities and lopinavir/ritonavir or other HIV protease inhibitors because of unfavorable pharmacodynamics and negative clinical trial data. Except in the context of a clinical trial, the Panel advised against the use of other immunomodulators, such as IFNs, because of lack of efficacy in the treatment of SARS and MERS and their toxicity and Janus kinase inhibitors (e.g., baricitinib), due to their broad immunosuppressive effect (62).

\section{Umbilical Cord Mesenchymal Stem Cell (UC-MSC) Transplantation}

According to the clinical data, UC-MSCs and MCS have antiinflammatory, immunomodulatory and antimicrobial actions, thereby, it can heal damaged tissues. The target tissue for stem cells is where they are caught by the lungs, as this is a favorable condition for COVID-19 treatment.

The clinical condition of elderly patients or patients with secondary comorbidities may progress worse and may not response to conventional treatment. For critically ill patients, infected with SARS-CoV-2, MSC therapy is the last resort and it can save lives. Unfortunately, even if MCS treatment has been previously attempted in different diseases, it is a new and inexperienced treatment method for COVID-19 (63).

In a clinical study presenting positive responses of seven COVID-19 pneumonia patients to MSC, genetic examination showed that MSCs are negative for ACE2 and the cellular protease TMPRSS2, which are known to be exempt from COVID-19 infection. Bone marrow, lymph nodes, thymus, and the spleen, immune cells, such as $\mathrm{T}$ and $\mathrm{B}$ lymphocytes, and macrophages were consistently negative for ACE2, as well. Therefore, intravenous transplantation of MSCs is likely to be a safe and effective option for the treatment of patients with COVID-19 pneumonia at the critically severe stage $(63,64)$.

\section{Vaccine Developments}

It is necessary to overcome various difficulties to succeed in vaccine production. Many vaccine studies are carried out worldwide in accordance with phase 1 through phase 4 trial steps (65).

Moderna, Inc. is manufacturing therapeutics and vaccines for infectious diseases, immuno-oncology, rare diseases and cardiovascular diseases with collaborators as the Vaccine Research Center at the NIAID. mRNA-1273 is an mRNA vaccine, developed by Moderna, against SARS-CoV-2 encoding for a prefusion stabilized form of the Spike (S) protein. mRNA-1273 inhibits viral replication in the lungs of mice in the responding stage to SARS-CoV-2 infection. It is finalizing the protocol for a Phase 3 trial, phase IV "post-approval” studies will probably start in July $2020(65,66)$.

\section{Conclusion}

Currently, no specific treatment has been approved by the FDA in the treatment or prophylaxis of COVID-19 disease, except for Remdesivir. Despite the claim in medical literature and some clinical studies regarding the achievement of cure in COVID-19 patients using various therapeutics, appropriate clinical research results are needed to identify optimal treatments for COVID-19.

For the current clinical management, supportive care is recommended, including infection prevention and control measures and respiratory support when indicated. As with general patient management, the healthcare provider makes decisions based on the patient's condition and characteristics.

Peer-review: Externally peer-reviewed.

\section{Authorship Contributions}

Concept: H.E.M.A., Ö.Ö., Design: H.E.M.A., Ö.Ö., Analysis or Interpretation: H.E.M.A., Ö.Ö., Literature Search: H.E.M.A., Ö.Ö., Writing: H.E.M.A.

Conflict of Interest: No conflict of interest was declared by the authors.

Financial Disclosure: The authors declared that this study received no financial support.

\section{References}

1. Prajapat M, Sarma P, Shekhar N, Avti P, Sinha S, Kaur H. Drug targets for corona virus: A systematic review. Indian J Pharmacol 2020:52:56-65.

2. Özdemir Ö, Pala A. Çocuklarda COVID-19 Enfeksiyonunun Tanısı, Tedavisi ve Korunma Yolları. J Biotechinol and Strategic Health Res 2020;4:21-14.

3. Abd El-Aziz TM, Stockand JD. Recent progress and challenges in drug development against COVID-19 coronavirus (SARS-CoV-2) an update on the status. Infect Genet Evol 2020;83:104327. 
4. Lombardy Section Italian Society I, Tropical D. Vademecum for the treatment of people with COVID-19. Edition 2.0 Infez Med 2020;28:2:143-52.

5. National Health Commission of the People's Republic of China. Guidelines for the Prevention, Diagnosis, and Treatment of Novel Coronavirus-induced Pneumonia. 7th ed; 2020 Available from: http://www.gov.cn/zhengce/zhengceku/2020-03/04/5486705/files/ ae61004f930d47598711a0d4cbf874a9.pdf

6. The American Society of Health-System Pharmacists. Aralen Phosphate. 2015 Access date: 5 may 2020 Available from: https:// www.ashp.org/?loginreturnUrl=SSOCheckOnly

7. Zhou D, Dai SM, Tong Q. COVID-19: A recommendation to examine the effect of hydroxychloroquine in preventing infection and progression. J Antimicrob Chemother 2020;75:1667-70.

8. Cortegiania A, Ingoglia G, Ippolitoa M, Giarratanoa A, Einav S. A systematic review on the efficacy and safety of chloroquine for the treatment of COVID-19. J Crit Care 2020;57:279-83.

9. J-Marc C, Jean R, Lagierab C, Brouquiab P, Raoul D. Chloroquine and hydroxychloroquine as available weapons to fight COVID-19. Int J Antimicrob Agents 2020;55:105932.

10. Gao J, Tian Z, Yang X. Breakthrough: Chloroquine phosphate has shown apparent efficacy in treatment of COVID-19 associated pneumonia in clinical studies. Biosci Trends 2020;14:1:72-3.

11. Wang M, Cao R, Zhang L, Yang X, Liu L, Xu M, et al. Remdesivir and chloroquine effectively inhibit the recently emerged novel coronavirus (2019-nCoV) in vitro. Cell Res 2020;30:3:269-71.

12. Efficacy and safety of chloroquine phosphate inhalation combined with standard therapy in the treatment of novel coronavirus pneumonia (COVID-19) Last Accessed Date: 17.03.2020. Available from: https:// apps.who.int/trialsearch/Trial2.aspx?TrialID=ChiCTR2000030417

13. Gautret P, Lagier JC, Parola P, Meddeb L, Mailhe M, Doudier B, et al. Hydroxychloroquine and azithromycin as a treatment of COVID-19: results of an open-label non-randomized clinical trial. Int J Antimicrob Agents 2020; 56(1):105949.

14. Magagnoli J, Narendran S, Pereira F, Cummings T, Hardin JW, Sutton SS, et al. Outcomes of hydroxychloroquine usage in United States veterans hospitalized with Covid-19. Medrxiv 2020;04:20065920.

15. Mehra MR, Desai SS, Frank Ruschitzka F, Patel AN. Hydroxychloroquine or chloroquine with or without a macrolide for treatment of COVID-19: a multinational registry analysis. Lancet 2020;395:1820.

16. COVID-19 (SARS-CoV2 Infection) Directory (Science Committee Work). T.R. Ministry of Health, 2 April 2020

17. WebMD. Chloroquine Side Effects: Common, Severe, Long Term. Last Accessed Date: 22.03.2020. Available from: www.webmd.com. https://www.webmd.com/drugs/2/drug-8633/chloroquine-oral/ details

18. Centers for Disease Control and Prevention. CDC Health Information for International Travel 2018. New York: Oxford University Press; 2018.

19. Dyall J, Coleman CM, Hart BJ, Venkataraman T, Holbrook MR, Kindrachuk J, et al. Repurposing of clinically developed drugs for treatment of Middle East respiratory syndrome coronavirus infection. Antimicrob Agents Chemother 2014;58:4885-93.
20. Fan HH, Wang LQ, Liu WL, Ann XP, Liu ZD. Repurposing of clinically approved drugs for treatment of coronavirus disease 2019 in a 2019-novel coronavirus-related coronavirus model. Chin Med J (Engl) 2020;133:1051-6.

21. Food and Drug Administration. Fact sheet for health care providers: Emergency use authorization of remdesivir. Last AccessHYPERLINK "https://www.fda.gov/media/137566/download\%20access $\% 20$ date\%20May\%202020"

22. Japan Approves Gilead's Remdesivir to Treat Covid-19, NHK Says. Bloomberg Last Accessed Date: 07.03.2020. Available from: https:// www.bloomberg.com/news/articles/2020-05-07/japan-set-toapprove-remdesivir-for-coronavirus-on-thursday

23. Sheahan TP, Sims AC, Graham RL, Menachery VD, Gralinski LE, Case JB, et al. Broad-spectrum antiviral GS-5734 inhibits both epidemic and zoonotic coronaviruses. Sci Transl Med 2017;9:eaal3653.

24. Williamson BN, Feldmann F, Schwarz B, Meade-White K, Porter DP, Schulz J, et al. Clinical benefit of remdesivir in rhesus macaques infected with SARS-CoV-2. bioRxiv [Preprint]. 2020.04.15.043166.

25. Grein J, Ohmagari N, Shin D, Diaz G, Asperges E, Castagna A. Compassionate Use of Remdesivir for Patients with Severe Covid-19. N Engl J Med 2020;382:2327-36.

26. Sheahan TP, Sims AC, Leist SR, Schafer A, Won J, Brown AJ, et al. Comparative therapeutic efficacy of remdesivir and combination lopinavir, ritonavir, and interferon beta against MERS-CoV. Nat Commun 2020;11:222.

27. WHO R\&D Blueprint Informal consultation on prioritization of candidate therapeutic agents for use in novel coronavirus 2019 infection Geneva, Switzerland. Last Accessed Date: 24.01.2020. Available from: https://apps.who.int/iris/bitstream/ handle/10665/330680/WHO-HEO-RDBlueprint\%28nCoV\%292020.1-eng.pdf

28. NIH Clinical Trial Shows Remdesivir Accelerates Recovery from Advanced COVID-19. (cited 2020 April, 29) Available from: https:// www.niaid.nih.gov/news-events/nih-clinical-trial-shows-remdesiviraccelerates-recovery-advanced-covid-19

29. Wang Y, Zhang D, Du G, Du R, Zhao J, Jin Y, et al. Remdesivir in adults with severe COVID-19: A randomised, double-blind, placebocontrolled, multicentre trial. Lancet 2020; 395: 1569-78.

30. National Institute of Allergy and Infectious Diseases (NIAID). Investigational Therapeutics for the Treatment of People With Ebola Virus Disease. ClinicalTrials.gov Identifier: NCT03719586. March 2020. Available from: https://clinicaltrials.gov/ct2/show/ NCT03719586? term=randomized+ebola\&draw $=2$.

31. Stockman LJ, Bellamy R, Garner P. SARS: systematic review of treatment effects. PLoS Med 2006;3:9:e343.

32. Chu CM, Cheng VC, Hung IF, Wong M, Chan K, Kao R, et al. Role of lopinavir/ritonavir in the treatment of SARS: Initial virological and clinical findings. Thorax 2004;59:252-6.

33. Arabi YM, Shalhoub S, Mandourah Y. Ribavirin and interferon therapy for critically ill patients with Middle East respiratory syndrome: a multicenter observational study. Clin Infect Dis 2020;70:1837-44.

34. Ranieri VM, Pettila V, Karvonen MK, Jalkanen J, Nightingale P, Brealey D, et al. Effect of intravenous interferon beta-1a on death and 
days free from mechanical ventilation among patients with moderate to severe acute respiratory distress syndrome: a randomized clinical trial. JAMA. 2020 Feb 17. doi: 10.1001/jama.2019.22525. Online ahead of print. https://www.ncbi.nlm.nih.gov/pubmed/32065831.

35. Recommendations for the Use of Antiretroviral Drugs in Pregnant Women with HIV Infection and Interventions to Reduce Perinatal HIV Transmission in the United States. (Cited 2020 April) Available from: https://aidsinfo.nih.gov/guidelines/html/3/perinatal/0

36. Kim UJ, Won EJ, Kee SJ, Jung SI, Jang HC. Combination therapy with lopinavir/ritonavir, ribavirin and interferon- $\alpha$ for Middle East respiratory syndrome. Antivir Ther 2016;21:455-9.

37. Cao B, Wang Y, Wen D, Liu W, Wang J, Fan G, Ruanet L, et al. A Trial of Lopinavir-Ritonavir in Adults Hospitalized with Severe Covid-19. N Engl J Med 2020;382:1787-99.

38. Bai CQ, Mu JS, Kargbo D, Song YB,Niu WK, Nie WM, et al. Clinical and virological characteristics of Ebola virus disease patients treated with favipiravir (T-705)-Sierra Leone, 2014. Clin Infect Dis 2016:63;1288-94

39. Chen C, Huang J, Cheng Z, Wu J, Chen S, Zhang Y, et al. Favipiravir versus Arbidol for COVID-19: a randomized clinical trial. medRxiv 2020.03.17.20037432.

40. Cai Q, Yang M, Liu D, Chen J, Shu D, Xia J, et al. Experimental treatment with Favipiravir for COVID-19: An Open-Label Control Study. Engineering https://doi.org/10.1016/j.eng.2020.03.007. (epub ahead of print].

41. Siemieniuk RAC, Meade MO, Alonso-Coello P, Briel M, Evaniew N, Prasad M, et al. Corticosteroid Therapy for Patients Hospitalized With Community-Acquired Pneumonia: A Systematic Review and Meta-analysis. Ann Intern Med 2015;163:519-28.

42. Russell CD, Millar JE, Baillie JK. Clinical evidence does not support corticosteroid treatment for 2019-nCoV lung injury. Lancet 2020;395:10223:473-5.

43. Zhao JP, Hu Y, Du RH, Chen ZS, Jin Y, Zhou M, et al. Expert consensus on the use of corticosteroid in patients with 2019-nCoV pneumonia (in Chinese). Zhonghua Jie $\mathrm{He} \mathrm{He} \mathrm{Hu} \mathrm{Xi} \mathrm{Za} \mathrm{Zhi}$ 2020;43:E007.

44. Sun F, Kou H, Wang S, Yun L, Zhao H, Li W, et al. Medication Patterns and Disease Progression Among 165 Patients with Coronavirus Disease 2019 (COVID-19) in Wuhan, China: A SingleCentered, Retrospective, Observational Study. SSRN Electronic Journal. 10.2139/ssrn.3551323.

45. Bi J, Yang J, Wang Y, Yao C, Mei J, Liu Y, et al. Efficacy and safety of adjunctive corticosteroids therapy for severe community-acquired pneumonia in adults: an updated systematic review and metaanalysis. PLoS One 2016;15:e0165942.

46. Tsai MJ, Yang KY, Chan MC, Kao KC, Wang HC, Perng WC, et al. Impact of corticosteroid treatment on clinical outcomes of influenzaassociated ARDS: A nationwide multicenter study. Ann Intensive Care 2020:27;10:26.

47. Shanghai Expert Consensus on Covid-19 Treatment. Last Accessed Date: 23.03.2020. Available from: http://www.drwlc. com/blog/2020/03/21/shanghai-expert-consensus-on-covid-19treatment/
48. High-dose intravenous vitamin C treatment for COVID-19 (a mechanistic approach) Erol Project Development House for the disorders of energy metabolism Silivri-Istanbul, Turkey DO10.13140/RG.2.2.28639.20646

49. Fowler AA, Truwit JD, Hite RD, Morris PE, DeWilde C, Priday A, et al. Effect of Vitamin C Infusion on Organ Failure and Biomarkers of Inflammation and Vascular Injury in Patients With Sepsis and Severe Acute Respiratory Failure: The CITRIS-ALI Randomized Clinical Trial. JAMA 2019:1;322:1261-70.

50. Zhang J, Ma X, Yu F, Liu J, Zou F, Pan T, et al. Teicoplanin potently blocks the cell entry of 2019-nCoV. bioRxiv 2020.02.05.935387

51. Baron SA, Devaux C, Colson P, Raoult D, Rolain JM. Teicoplanin: an alternative drug for the treatment of COVID-19? Int J Antimicrob Agents 2020;55:105944.

52. Xu X, Han M, Li T, Sun W, Wang D, Fu B, et al. Effective treatment of severe COVID-19 patients with tocilizumab. Proc Natl Acad Sci USA 2020;117:10970-5

53. NIH. Tocilizumab. Clinical Trials. Last Accessed Date: 28.04.2020. Available from: https://clinicaltrials.gov/ct2/results?cond=covid$19+$ tocilizumab \&term $=\&$ cntry $=\&$ state $=\&$ city $=\&$ dist $=\&$ Search $=$ Sea rch

54. Choy KT, Wong A, Kaewpreedee P, Sia SF, Chen D, Yan Hui KP, et al. Remdesivir, lopinavir, emetine, and homoharringtonine inhibit SARS-CoV-2 replication in vitro. Antiviral Res 2020;178:104786.

55. Patrì A. Fabbrocini G. Hydroxychloroquine and ivermectin: a synergistic combination for COVID-19 chemoprophylaxis and/or treatment? J Am Acad Dermatol 2020;82:e221.

56. Patel AN, Desai AS, Grainger DW, Mehra MR. Usefulness of Ivermectin in COVID-19 Illness. Last Accessed Date: 19.04.2020. Available from: https://papers.ssrn.com/sol3/papers.cfm?abstract_ id=3580524 under review by SSRN.

57. Chen N, Zhou M, Dong X, Qu J, Gong F, Han Y, et al. Epidemiological and clinical characteristics of 99 cases of 2019 novel coronavirus pneumonia in Wuhan, China: a descriptive study. Lancet 2020;395:10223:507-13.

58. Özdemir Ö, Melek Arsoy HE. Convalescent (immune) plasma therapy with all aspects: yesterday, today and COVID-19. Erciyes Med J 2020;42:252-9.

59. Dalakas MC, Clark WM. Strokes, thromboembolic events, and IVIg: Rare incidents blemish an excellent safety record. Neur 2003;60:1736-7.

60. Xie Y, Cao S, Li Q, Chen E, Dong H, Zhang W, et al. Effect of regular intravenous immunoglobulin therapy on prognosis of severe pneumonia in patients with COVID-19 J Infect 2020;81:318-56.

61. Siddiqi HK, Mehra MR. COVID-19 Illness in Native and Immunosuppressed States: A Clinical-Therapeutic Staging Proposal. J Heart Lung Transplant 2020;39:405-7.

62. NIH. Potential Antiviral Drugs Under Evaluation for the Treatment of COVID-19. Last Accessed Date: 12.05.2020. Available from: https://www.covid19treatmentguidelines.nih.gov/therapeuticoptions-under-investigation/

63. Leng Z, Zhu R, Hou W. Transplantation of ACE2 Mesenchymal stem cells improves the outcomes of patients with COVID-19 pneumonia. Aging Dis 2020;11:216-28. 
64. Hamming I, Timens W, Bulthuis MLC, Lely AT, Navis GJ, van Goor $H$. Tissue distribution of ACE2 protein, the functional receptor for SARS coronavirus. A first step in understanding SARS pathogenesis. J Pathology 2004:203:631-7.

65. Moderna . Moderna Announces Positive Interim Phase 1 Data for its mRNA Vaccine (mRNA-1273) Against Novel Coronavirus. Last Accessed Date: 18.03.2020. Available from: https://investors. modernatx.com/node/8986/pdf
66. Amanat F, Krammer F. SARS-CoV-2 Vaccines: Status Report. Immunity 2020:52;4;583-9

67. Tönnesmann E, Kandolf R, Lewalter T. Chloroquine cardiomyopathy - A review of the literature. Immunopharm Immunotoxicol. 2013:35:434-42. 